\title{
Oceanic Diet and Distribution of Haplotypes for the Green Turtle, Chelonia mydas, in the Central North Pacific ${ }^{1}$
}

\author{
Denise M. Parker, ${ }^{2,3}$ Peter H. Dutton, ${ }^{4}$ and George H. Balazs ${ }^{5}$
}

\begin{abstract}
A diet analysis was conducted on the gastrointestinal contents of 10 oceanic green turtles, Chelonia mydas, collected as bycatch mortalities in pelagic fisheries. Size distribution of the green turtles ranged from 30 to $70 \mathrm{~cm}$ curved carapace length (CCL). Prey items found indicated pelagic green turtles to be carnivorous with some omnivorous tendencies, foraging within the first $100 \mathrm{~m}$ of the water column. Most frequent identifiable prey items were zooplankton, pelagic crustaceans, and mollusks (listed in order of frequency of occurrence, which ranged from $80 \%$ to $40 \%$ frequency): Pyrosoma spp., Lepas spp. (goose barnacles), amphipods, Carinaria spp. (sea snails), and Cavolinia spp. (sea butterflies). Other coelenterates such as salps, ctenophores, and cnidarians (jellyfish) were also identified. Plastics and anthropogenic debris were commonly found $(70 \%$ frequency, mean $=4 \%$ of gastrointestinal content by volume). The turtles examined consisted of two distinct morphotypes corresponding to the central Pacific and the eastern Pacific green turtle populations. Genetic analysis confirmed turtles of the central Pacific morphotype to be of Hawaiian origin and at least one of the eastern Pacific morphotype turtles to have a mtDNA haplotype found in the population nesting in the Revillagigedo archipelago off Mexico. Other eastern Pacific morphotypical turtles had a different common Mexican haplotype found among the nesting populations throughout Mexico and the Galápagos. Turtles of the central Pacific morphotype were distributed north of the Hawaiian Islands, and turtles of the eastern Pacific morphotype were all encountered south of Hawai' $i$, suggesting a dichotomy in the oceanic distribution of these two populations. Our records of green turtles as large as $70 \mathrm{~cm}$ CCL in pelagic waters suggest that some green turtles, mainly those with eastern Pacific green turtle morphology and mtDNA haplotype, delay their recruitment to nearshore (neritic) habitats or move back and forth between neritic and open ocean waters as adults.
\end{abstract}

\footnotetext{
${ }^{1}$ Manuscript accepted 31 January 2011.

${ }^{2}$ Joint Institute for Marine and Atmospheric Research, National Oceanic and Atmospheric Administration, 1315 East-West Highway SSMC3 F/SF1-13525, Silver Spring, Maryland 20910.

${ }^{3}$ Corresponding author (e-mail: Denise.Parker@ noaa.gov).

${ }^{4}$ National Oceanic and Atmospheric Administration, National Marine Fisheries Service, Southwest Fisheries Science Center, 8604 La Jolla Shores Drive, La Jolla, California 92037.

${ }^{5}$ National Oceanic and Atmospheric Administration, National Marine Fisheries Service, Pacific Islands Fisheries Science Center, 2570 Dole Street, Honolulu, Hawai'i 96822-2396.
}

Pacific Science (2011), vol. 65, no. 4:419-431

doi: $10.2984 / 65.4 .419$

Work of the U.S. Government

Not under copyright
Green turtles, Chelonia mydas (L.), are found in tropical and subtropical oceans worldwide. Currently, they are listed as endangered in the IUCN World Conservation Union Red data book (Hilton-Taylor 2000, Seminoff 2004). The United States Endangered Species Act of 1978 lists the green turtle as endangered in Florida and Pacific Mexico and threatened elsewhere in the United States (National Marine Fisheries Service and U.S. Fish and Wildlife Service 1998a, b). Chelonia mydas in the Pacific Ocean includes two morphotypes that are very different in appearance, but they are still considered the same species even though genetic differences have been detected (Dutton et al. 1996, National Marine Fisheries Service and U.S. Fish 


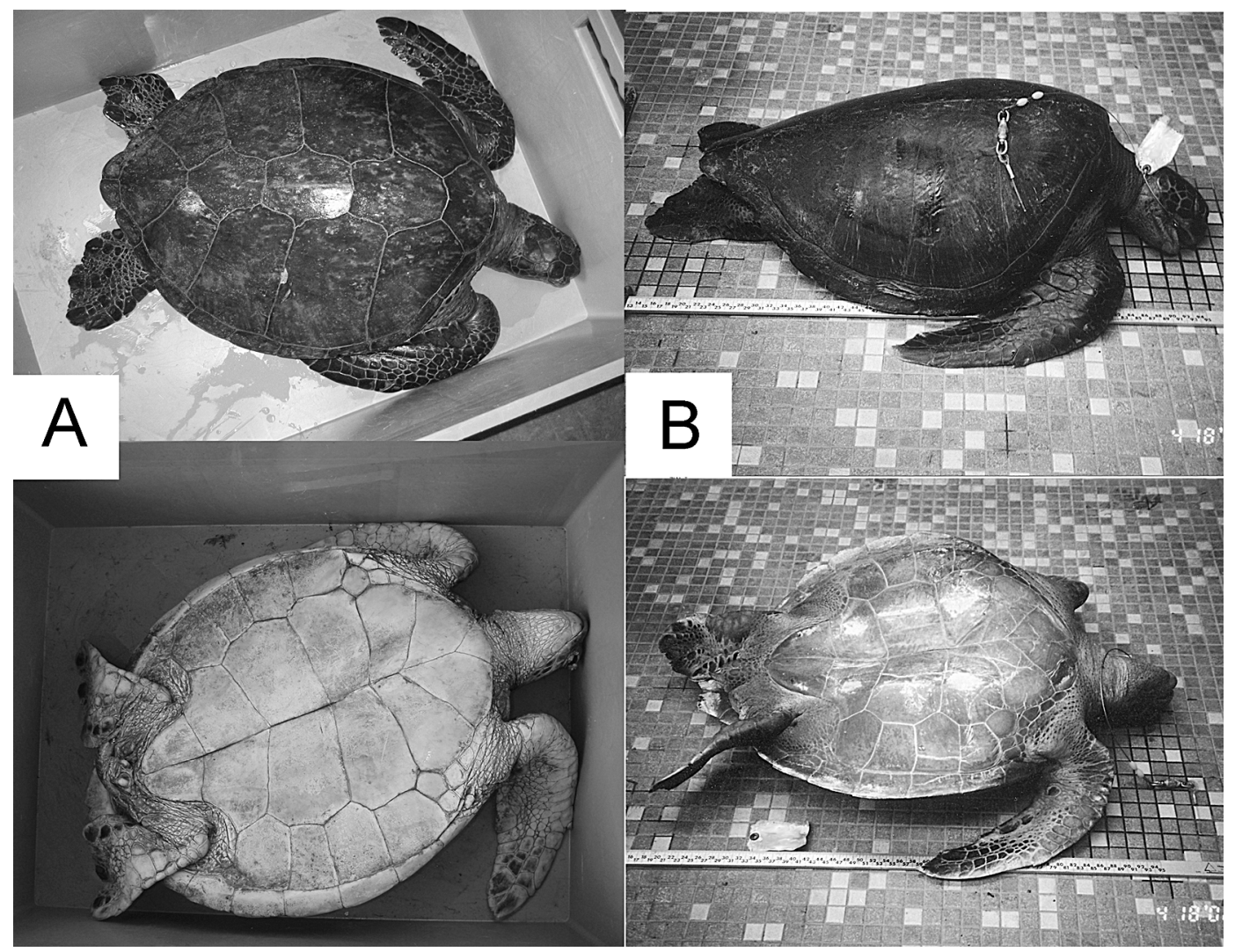

Figure 1. (A) A morphotypical green turtle (C. mydas, Hawaiian Island stranding): oval, light brown to black carapace (top) with thick scutes, and cream to yellow plastron (bottom); $(B)$ green turtle (longline bycatch) displaying the morphological characteristics of an eastern tropical Pacific green turtle: heart-shaped black carapace (top), with thin scutes and gray plastron (bottom).

and Wildlife Service 1998b) (Figure 1). The lighter-colored morphotype is found worldwide, and a melanistic form is located mainly in the East Pacific (Groombridge and Luxmoore 1989, National Marine Fisheries Service and U.S. Fish and Wildlife Service $1998 a, b)$.

Hatchling green turtles emerge from their nests and enter the oceanic realm. Afterward, little is known about their ecological niche until they enter nearshore (neritic) benthic foraging grounds. According to a number of hypotheses, the recently hatched turtles stay in the open ocean, and this pelagic phase lasts between 5 and 10 yr (Zug et al. 2002, Reich et al. 2007). While in the pelagic phase, all turtle species are mainly carnivorous (Davenport and Balazs 1991, Parker et al. 2005, Reich et al. 2007, Boyle and Limpus 2008). However, little is known about $C$. mydas during this phase. It has been assumed that they associate with Sargassum drift lines in the Atlantic Ocean, similar to loggerhead posthatchlings (Caldwell 1963, Carr and Meylan 1980). However, during a survey conducted by Witherington (2002) of juvenile Caretta caretta in Florida Current drift lines, no posthatchlings of $C$. mydas were observed. The pronounced counter shading of the hatchlings suggests that posthatchling $C$. mydas may dwell more in open waters rather than in and among algal mats (Bustard 1970, Musick and 
Limpus 1997; but see Balazs [1986] regarding transitional plastron coloration). A recent study in the Atlantic suggests that green turtles likely do associate with algal mats; however their tendency to dive quickly with a burst of speed and hide within the algal mat makes it difficult to observe neonate turtles in the wild (Smith and Salmon 2009). Juvenile green turtles have been observed in association with floating Macrocystis spp. (kelp) mats in the eastern tropical Pacific (Pitman 1990, Nichols et al. 2001); however few juvenile green turtles have been sighted on the high seas in the central Pacific, except as fisheries bycatch.

Soon after recruiting to neritic habitats, $C$. mydas becomes mainly herbivorous (Bjorndal 1997). Most green turtles recruit to a benthic foraging habitat after the passage of their 5to $10-y r$ pelagic phase when they reach sizes ranging from around $40-45 \mathrm{~cm}$ curved carapace length (CCL) in Australia (Limpus et al. 1994) to $35-45 \mathrm{~cm}$ straight carapace length (SSL) in Hawai' $i$ and 30-45 cm SSL in Baja California, Mexico (Balazs et al. 1987, Zug et al. 2002, Seminoff et al. 2003). Knowledge of C. mydas feeding ecology comes mainly from studies conducted on these neritic habitats (Mortimer 1982, Bjorndal 1985, Balazs et al. 1987, Burke et al. 1991, Seminoff et al. 2002). Sea grass and seaweed are the most preferred benthic forage when it is available (Pritchard 1977). Although nearly $95 \%-99 \%$ of the neritic green turtle diet is made up of plant matter, a small percentage can also consist of animal material such as jellyfish (Limpus 1978, Arthur and Balazs 2008), sea pens, sponges, or various other benthic invertebrates (HaysBrown and Brown 1982, Burke et al. 1991, Ferreira et al. 2006, Amorocho and Reina 2007, Arthur and Balazs 2008).

The foraging ecology of pelagic turtles is a growing area of research. Salmon et al. (2004) reported the oceanic foraging habits of young captive-reared juvenile green turtles in the Atlantic Ocean. A diet analysis of stranded posthatchling turtles was also conducted along the east coast of Australia (Boyle and Limpus 2008), but few diet studies have been conducted on postneonate oceanic green turtles. In this paper, we report on the diet and sizes of oceanic green turtles in the central North Pacific region and discuss how this may relate to their genetic stock origin, morphotype, and life histories.

\section{MATERIALS AND METHODS}

We conducted diet analyses of gastrointestinal (GI) contents on 10 oceanic green turtles collected as bycatch mortalities in pelagic fisheries. Four of the green turtles were collected by National Marine Fisheries Service (NMFS) observers during 1990-1991 in the North $\mathrm{Pa}$ cific high-seas drift-net fishery. Six other $C$. mydas were collected by NMFS observers during 1999-2004 in the Hawai'i-based pelagic longline fishery. NMFS observers recorded the capture position, measured CCL (nearest $0.5 \mathrm{~cm}$ ), and collected a skin sample from each turtle. Skin samples were taken from all turtles with a $6 \mathrm{~mm}$ skin biopsy punch and stored in salt and frozen until they could be transferred into DMSO solution (Dutton and Balazs 1995). Whole turtles were then sent to the Pacific Islands Fisheries Science Center (PIFSC) for necropsy. We noted the morphological characteristics of the green turtles during necropsy. We assigned a central or morphotypical C. mydas (CmM) morphology if the turtle had a typical oval carapace that ranged from light to dark brown in coloration and if the plastron was cream to orange in coloration (Carr 1952, National Marine Fisheries Service and U.S. Fish and Wildlife Service 1998a, Wyneken 2001) (Figure $1 A)$. We assigned an eastern tropical $\mathrm{Pa}$ cific (ETP) morphology if the turtle had a black to black-gray, highly domed heartshaped carapace and a grayish plastron (Carr 1967, Pritchard and Trebbau 1984, Figueroa and Alvarado 1991, National Marine Fisheries Service and U.S. Fish and Wildlife Service 1998b) (Figure 1B). The ETP (melanistic) form also typically had thinner carapical scutes than the $\mathrm{CmM}$ type (Figure $1 A, B$ ). We mapped the location of capture for each turtle using generic mapping tools as discussed in Ellis and Balazs (1998; see GMT in Wessel and Smith [1991]). We removed the GI contents and preserved them in a $10 \%$ formalin solution. Only stomach contents were col- 
lected and saved from six of the 10 samples. Full GI tract contents, with stomach contents and intestinal contents saved separately, were collected from the remaining four turtles. We made gross observations of GI contents using a dissecting microscope and sorted the contents to the lowest identifiable taxonomic level. We identified major fauna and quantified the volume of each prey group in the stomach sample using the displacement method (Hellawell and Abel 1971). We used only data for the stomach samples for statistical analyses. Reported average values are followed by \pm 1 standard deviation.

We performed Principal Component Analysis and K-Means Clustering (Pearson's correlation, Kruskal-Wallis comparison [twotailed] and Levene's test [XLSTAT 2010]) to compare foraging preferences between the $\mathrm{CmM}$ morphotype and the ETP morphotype $(\alpha=.05)$.

We conducted genetic analysis as described in Dutton et al. (2008) on tissue samples to obtain mtDNA sequences using the primers HDCM2 and LTCM2, designed to target 488 base pairs (bp) at the $5^{\prime}$ end of the control region of the mitochondrial genome (Lahanas et al. 1994). Sequences were aligned against reference data from the $384 \mathrm{bp}$ segment of the mtDNA control region corresponding to the region reported in Dethmers et al. (2006) and Dutton et al. (2008) to identify haplotypes and assign most likely nesting stock origin.

\section{RESULTS}

Prey groups, mean percentage volume of prey, and frequency of occurrence for each prey group are listed in Table 1. The most commonly identifiable prey items were Pyrosoma spp., which we found in $80 \%$ of $C$. mydas stomachs, and we found unidentifiable material in $80 \%$ of all stomachs. One stomach contained $100 \%$ Pyrosoma, but among all turtles Pyrosoma averaged $35.2 \%( \pm 42.4 \%)$ of the total prey volume. The results of the K-Means cluster analysis show that Pyrosoma make up an individual group, unidentified remains make up another individual group, and all other prey items are considered a third group $(P<.0001, \alpha=.5)$. We also commonly en- countered Lepas spp. (goose barnacles, 70\% frequency and $13.7 \% \pm 22.3 \%$ by volume). We encountered cnidarians less frequently (jellyfish, siphonophores; $50 \%$ frequency and $1.9 \% \pm 3.5 \%$ by volume for stomach only). fanthina spp. (violet snails) were present but occurred infrequently (30\% frequency) and in low volumes $(0.8 \% \pm 1.9 \%$ of total volume). Anthropogenic debris, including small soft and hard plastic pieces, polypropylene line, and monofilament line, was common $(70 \%$ frequency), averaging $4 \%$ of total volume, with a maximum volume of $11 \%$ in one sample. Algae were not commonly encountered (20\% frequency), although Rhodophyta composed roughly $27 \%$ of the total volume for one sample, and Turbinaria ornata composed $7 \%$ of the total volume in another sample. Twenty-nine percent of the stomach contents by volume were unidentifiable as a result of the digestion process. The total volume of prey found in the stomach samples ranged from 24 to $315 \mathrm{ml}$. There were no significant differences in prey items between the two turtle morphotypes (Kruskal-Wallis, $P=.114$, Pearson correlation coefficient $=0.9$ ). The distribution of the oceanic green turtles sampled ranged in an area from $5.6^{\circ}$ to $33^{\circ} \mathrm{N}$ latitude and $159^{\circ} \mathrm{E}$ to $154^{\circ} \mathrm{W}$ longitude (Figure 2). All turtles were captured at a distance between 60 and 1,700 km from any landmass and over water depths between 1,890 and $5,780 \mathrm{~m}$. The size distribution for green turtle specimens ranged from 30.0 to $70.5 \mathrm{~cm}$ CCL with a mean of $48.1 \mathrm{~cm} \pm 12.4$ ( $n=10$ turtles). All drift-net fisheries turtles were sampled north of the Hawaiian Islands. Longlinecaptured turtles were sampled both north and south of the Hawaiian Islands (Figure 2).

We determined mtDNA haplotypes for six of the 10 turtles, including two of the four drift-net-captured and four of the six Hawai' $i$ longline-captured turtles. The other four samples were too degraded for proper analysis (Figure 2). The two drift-net-captured turtles we were able to sequence had a common $\mathrm{Ha}$ waiian haplotype, CmP1 (Dutton et al. 2008), and the other two turtles had morphological characteristics consistent with the $\mathrm{CmM}$ morphotype. Three of six longline-captured turtles we sequenced had a common eastern $\mathrm{Pa}$ - 
TABLE 1

Frequency of Occurrence (\% of Stomachs) and Mean Percentage of Total Volume ( \pm 1 Standard Deviation [SD]) for Prey Items (Listed to Lowest Resolvable Taxonomic Rank) Found in Green Sea Turtle (Chelonia mydas) Stomachs $(n=10)$

\begin{tabular}{|c|c|c|}
\hline Prey Group & $\begin{array}{l}\text { \% Volume } \\
\quad( \pm 1 \text { SD })\end{array}$ & $\begin{array}{c}\text { Frequency of } \\
\text { Occurrence (\%) }\end{array}$ \\
\hline \multicolumn{3}{|l|}{ Algae } \\
\hline Phaeophyta: Turbinaria ornata & 7.0 & 10 \\
\hline Rhodophyta & 26.7 & 10 \\
\hline \multicolumn{3}{|l|}{ Coelenterata: Hydroida } \\
\hline Pyrosomatidae: Pyrosoma atlanticum & $35.2( \pm 42.4)$ & 80 \\
\hline Cnidarians & $1.9( \pm 3.5)$ & 50 \\
\hline Salpidae & $0.8( \pm 1.5)$ & 40 \\
\hline Ctenophores & 3.1 & 10 \\
\hline \multicolumn{3}{|l|}{ Crustacea } \\
\hline Lepadidae (Lepas spp.) including L. anatifera anatifera and L. anserifera & $13.7( \pm 22.3)$ & 70 \\
\hline Amphipoda: Hyperidea (including Oxycephalus, Lycaea, Vibilia) & $0.5( \pm 1.3)$ & 60 \\
\hline Decapods: crabs: unidentified spp. parts & $0.6( \pm 1.3)$ & 20 \\
\hline Copepod & $<1.0$ & 10 \\
\hline \multicolumn{3}{|l|}{ Fishes } \\
\hline Scombridae: Scomber japonicus & 49.5 & 10 \\
\hline Ostraciidae: Lactoria diaphana (spiny cowfish) & 4.8 & 10 \\
\hline Flying fish eggs (Hirundicbthys speculiger) & $0.2( \pm 0.6)$ & 30 \\
\hline Unidentified spp. & 19.0 & 10 \\
\hline \multicolumn{3}{|l|}{ Mollusca: Gastropoda } \\
\hline Pterotracheids including Carinaria spp. & $3.5( \pm 6.2)$ & 60 \\
\hline Ptenoglossa: fanthina spp. & $0.8( \pm 1.9)$ & 30 \\
\hline Pteropoda: Cavolinia spp. including C. globulosa and C. tridentate & $1.1( \pm 2.8)$ & 30 \\
\hline \multicolumn{3}{|l|}{ Mollusca: Decopoda } \\
\hline Squid (Ommastrephes bartrami) & 47.6 & 10 \\
\hline Cephalopoda & 0.6 & 10 \\
\hline \multicolumn{3}{|l|}{ Marine debris } \\
\hline Artificial debris: Plastic & $3.5( \pm 4.3)$ & 70 \\
\hline Artificial debris: Polypropylene line & $1.4( \pm 3.1)$ & 40 \\
\hline Natural debris: Bird feathers & $<0.1$ & 30 \\
\hline Artificial debris: Monofilament & $<0.1$ & 20 \\
\hline Natural debris: Tree bark & 1.0 & 10 \\
\hline \multicolumn{3}{|l|}{ Other } \\
\hline Gnathosomulida mouthpart & $<0.1$ & 10 \\
\hline Coralline rock & 0.1 & 10 \\
\hline Unidentified remains & $28.9( \pm 30.4)$ & 80 \\
\hline
\end{tabular}

cific haplotype, $\mathrm{CmP} 4$ (Dutton et al. 2000, 2008), and all had the ETP morphotype. One of the longline specimens had a haplotype that occurs both in the Hawaiian and the eastern tropical Pacific nesting populations, CmP3 (Dutton et al. 2008), and that animal had the morphological characteristics of an ETP green turtle. Of the two longlinecaptured turtles we were unable to sequence, one had the typical CmM morphotype, and the other had morphological characteristics of an ETP green turtle (see Figure 2).

\section{DISCUSSION}

Diet

Our study analyzed C. mydas collected throughout oceanic environments in the central North Pacific and focuses on pelagic turtles (Figure 2). The prey items we describe in this study indicate that green turtles foraging on the high seas are opportunistic, mainly carnivorous, feeding at or near the surface (see Table 1). Gelatinous zooplankton (e.g., Pyrosoma, salps, ctenophores, and cnidarians) 


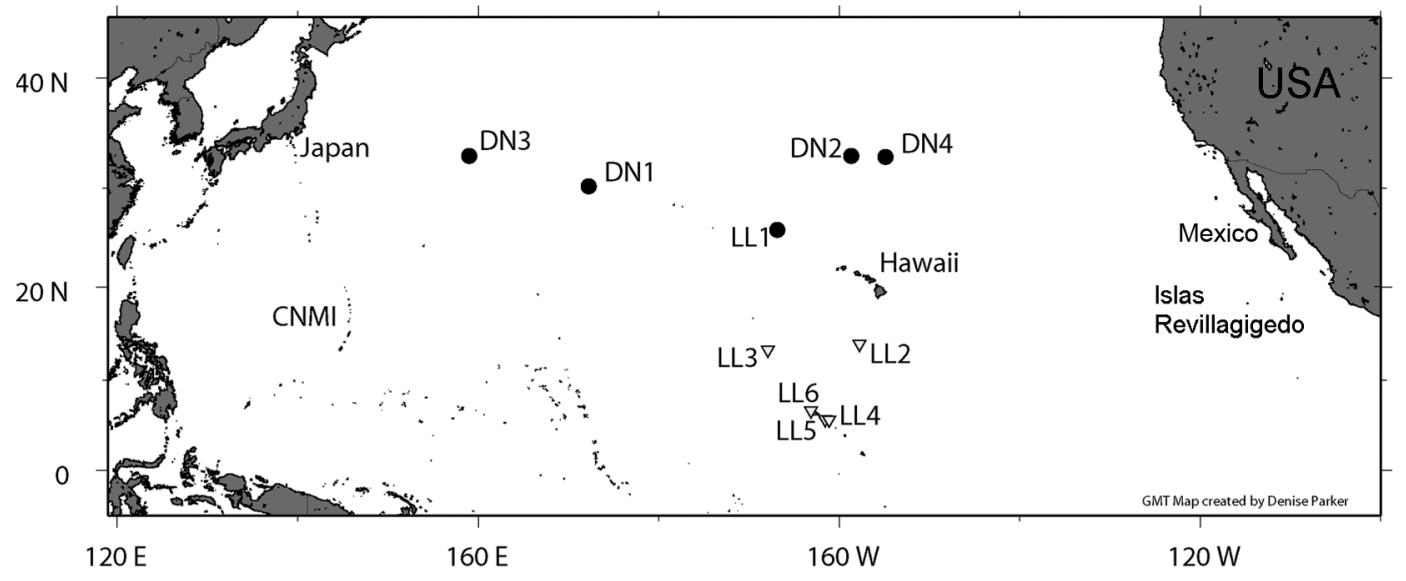

\begin{tabular}{|c|c|c|c|}
\hline ID & CCL, cm & Morphotype & Haplotype \\
\hline DN1 & 30 & CmM & CmP1 \\
\hline DN2 & 38 & CmM & CmP1 \\
\hline DN3 & 41 & CmM & --- \\
\hline DN4 & 44 & CmM & --- \\
\hline LL1 & 49 & CmM & --- \\
\hline LL2 & 42 & ETP & CmP4 \\
\hline LL3 & 46 & ETP & CmP3 \\
\hline LL4 & 58 & ETP & CmP4 \\
\hline LL5 & 65 & ETP & --- \\
\hline LL6 & 70 & ETP & CmP4 \\
\hline
\end{tabular}

FIGURE 2. Distribution of green turtles $(n=10)$ taken as bycatch in the high-seas drift-net fishery (DN, 1990-1992) and Hawai'i-based longline fishery (LL, 1999-2004). Curved carapace length is shown to the nearest centimeter (CCL, cm). Morphotypical Chelonia mydas $(\mathrm{CmM})$ are shown as black circles; eastern tropical Pacific morphotypes (ETP) are shown as inverted white triangles. mtDNA haplotypes in legend are indicated as follows: CmP1, Hawaiian Islands (central Pacific) haplotype; $\mathrm{CmP} 4$, eastern Pacific haplotype; and $\mathrm{CmP} 3$, Islas Revillagigedo rookery.

may also have made up part of the unidentified remains $(28.9 \% \pm 30.4 \%$ of total volume), because jellies are likely to be digested faster owing to their soft bodies, making clear identification difficult, especially when prey items were obtained from the intestinal tract. Although we did not quantify the volume of the intestinal contents of four of the 10 intestinal tract samples, we were able to easily identify and measure Pyrosoma bodies, shells from pelagic snails and barnacles, and debris for future analysis. Gelatinous zooplankton seems to be an important food source for all sea turtle species during their oceanic phase, because these foods have been documented as forage for green turtles as well as leatherbacks (Davenport and Balazs 1991), loggerheads
(Parker et al. 2005), and olive ridleys (Work and Balazs 2002, 2010). Davenport and Balazs (1991) suggested that Pyrosoma and other gelatinous zooplankton are likely targeted as prey not for their gelatinous bodies but for their stomachs or "nuclei," which are of higher nutritional value because they contain compacted phytoplankton, detritus, and microzooplankton. Pyrosoma were the most prevalent prey item that we found in eight out of 10 stomach samples.

Arenas and Hall (1991) reported a relationship between sea turtles and floating objects in the eastern tropical Pacific. We frequently observed goose barnacles (Lepas spp.), Carinaria spp. (sea snails), and sea butterflies (Cavolinia spp.) in our samples but not 
in large volumes. The goose barnacles would likely have been harvested from floating debris. Janthina spp., the violet snails, a prey group common in oceanic loggerhead diets (Parker et al. 2005), were not common in green turtle stomach samples we examined. Parker et al. (2005) also noted that Velella velella, by-the-wind sailors, was another common component of oceanic loggerhead diets, but this prey item was absent in all our green turtle stomach samples. Fanthina spp. usually prey on Velella, and these species could likely be found together or individually. Velella often occur in large rafts of many hundreds of individuals (Wrobel and Mills 1998). However, because of the small sample size, the lack of Velella in this study should be further investigated to determine if this indicates a dietary preference, omission due to sample size, or just an absence of Velella in the area where the turtles were foraging.

Our finding of plastic in $70 \%$ of the stomachs we examined is consistent with many previous studies that document the ingestion of plastics by sea turtles (Balazs 1985, Allen 1992, Shaver and Plotkin 1998, Tomás et al. 2002). During necropsy, there were no apparent blockages or adverse impact due to the ingestion of the plastic debris (Work and Balazs 2002). Consumption of plastic debris may not have any immediate lethal effect on the turtle (McCauley and Bjorndal 1999), but the decrease in nutritional value of a diet composed of debris may lead to detrimental effects, such as suboptimal health. Studies show increasing amounts of floating plastics in both the Pacific and Atlantic oceans (Day et al. 1990, Moore et al. 2001, Pichel et al. 2007, Barry 2009, Gill 2010, McLendon 2010), which may lead to an increase in plastic consumption by turtles, but future studies need to be done to validate this hypothesis.

Our findings indicate that the turtles likely are opportunistically feeding on bait. A healthy fish or squid would be difficult for a turtle to chase down and catch, so it is more likely that only dead or injured specimens of this prey type would be ingested. The presence of saba (Scomber japonicus), a common bait used in the Hawai'i-based longline fishery, and squid, Ommastrephes bartrami, the target species of the high-seas squid drift-net fishery (Wetherall et al. 1993), suggests that the oceanic green turtles were interacting with fishery gear and engaging in active dives for foraging purposes, and based on dives recorded for adult green turtles in the Hawaiian Islands these could have been as deep as or deeper than $135 \mathrm{~m}$ (Rice and Balazs 2008). However, we also found a spiny cowfish, Lactoria diaphana, which is not a bait item used in any fishery, in the stomach of a longline bycatch turtle. Although L. diaphana may be considered a reef fish, it is also known to live in the open ocean in both its juvenile and adult stages, confirmed from incidental records for adults of this species being noted in Micronesia from the stomachs of pelagic game fish (Myers 1999).

Some of the ingested items could have had land-based origins as well as an oceanic component. One turtle ingested some tree bark or wood. Whether the wood pieces were grazed from floating logs or from a neritic habitat is uncertain; however, logs and lumber have often been found in the open ocean and are often used as recruitment habitat for small fish, corals, and algae (Highsmith 1985, Jokiel 1989, Thil and Gutow 2005). Coralline rock material ingested could also have come from neritic habitat or been scraped off floating objects while the turtle was grazing on other prey items (Jokiel 1989). Another forage item typically thought of as land based was algae. Two morphotypical C. mydas specimens had algae as forage items. One drift-net-captured turtle had red algae (Rhodophyta) in its stomach contents, which could have been grazed as it ingested other prey items such as Lepas spp. The other turtle ingested a species of brown algae, Turbinaria ornata, which is commonly found growing attached to coral reef benches around the Hawaiian Islands. The longlinecollected turtle was captured north of French Frigate Shoals (FFS), Northwestern Hawaiian Islands, where T. ornata is established on the reefs (Vroom et al. 2006) and has been recorded as forage for the few resident green turtles that live year-round at FFS (Balazs 1980). The turtle was within $200 \mathrm{~km}$ of FFS at the time it was captured, so it may have come upon a raft of floating Turbinaria, or it could 
have foraged directly at FFS before returning to the pelagic zone because there was a low volume of Turbinaria in the intestine also.

\section{Genetics}

As noted, all drift-net-collected turtles were captured north of the Hawaiian Islands (Figure 2); those turtles were also all morphotypical (regular CmM type) C. mydas (Figure $1 A$ ). The one longline-collected turtle captured north of the Hawaiian Islands was a $\mathrm{CmM}$ type as well. Unfortunately, mtDNA haplotypes could not be obtained for all of the drift-net-caught turtles; although the genetic results we did obtain show that the regular $\mathrm{CmM}$ type green turtles belonged to the central Pacific (Hawaiian) genetic stock. However, because $\mathrm{CmM}$ morphotypes in this study were caught as far west as $155^{\circ} \mathrm{E}$ and we were unable to obtain genetic results from those specimens, it is possible that they may have come from western Pacific nesting beaches such as in Japan, Taiwan, or the Commonwealth of the Northern Mariana Islands or other numerous Pacific islands rookeries, rather than the Hawaiian archipelago (see Dethmers et al. 2006, Cheng et al. 2008). All of the longline-collected turtles captured south of the Hawaiian Islands had eastern $\mathrm{Pa}$ cific morphology (ETP morphotype or melanistic type [Figures $1 B, 2])$. Genetic analysis for turtles with ETP morphotypes indicated that they typically had the $\mathrm{CmP} 4 \mathrm{mtDNA}$ haplotype, commonly found at all the eastern Pacific nesting beaches, including the Galápagos and Mexico (Dutton et al. 2008), but not at any of the central or western Pacific rookeries surveyed to date (Dethmers et al. 2006, Cheng et al. 2008, Dutton et al. 2008). Our results suggest that these two different morphotypes encountered as juveniles on the high seas are from two distinct stocks: the $\mathrm{CmM}$ type from central and possibly western Pacific stocks, and the ETP morphotype from eastern Pacific stocks. Of the ETP morphotypical greens, one was determined to have a mtDNA haplotype ( $\mathrm{CmP3}$ [Figure 2]) found in low numbers in the central Pacific (Hawaiian) and only one ETP rookery, Islas Revillagigedo (Dutton et al. 2008), indicating that this turtle likely originated from that offshore Mexican archipelago, because that particular haplotype has not been found in any other ETP nesting population. These results suggest that the biogeographic barrier that has been noted for a broad range of marine fish (Ebeling and Weed 1963, Hubbs and Wisner 1980, Collette and Aadland 1996, Lessios and Robertson 2006) also may extend to the pelagic distribution of oceanic green turtles in the Pacific (P.H.D., S. Hargrove, and G.H.B., unpubl. data).

It is possible that there are two different life history pathways at work for the two turtle morphotypes. One life history is the "normal" life history cycle, where small pelagic green turtles spend 5-10 yr (Zug et al. 2002, Reich et al. 2007) in the oceanic environment and then recruit to a neritic forage habitat in the Pacific at between 35 and $45 \mathrm{~cm}$ SCL. This life history seems to be followed more closely by $\mathrm{CmM}$ type green turtles. The other life history cycle has an extended oceanic period or perhaps has the turtles moving between neritic and oceanic habitats throughout their life history, and we propose that this life history pathway is being used more often by those turtles of ETP morphology and genetics. Hatase et al. (2006) suggested that adult female green turtles foraged in the pelagic while moving between neritic and nesting areas; however the tracking did not indicate a prolonged stay for these turtles in the oceanic realm. Senko et al. (2010) recently published evidence that a small percentage of immature East Pacific green turtles moved between neritic foraging areas, because the turtles were recaptured in foraging areas 80-300 km away from their original capture site. During that time, the turtle could have been traveling along the coast or it could have also gone back into pelagic habitat, foraging in the open ocean while it moved between neritic foraging sites. Other evidence to support this divergence in life history comes from a study done by Seminoff et al. (2008), in which postnesting females were tracked from the Galápagos Islands, where two of the seven turtles tracked spent time in the open ocean for over a month. These results bolster the hypothesis that oceanic foraging behavior 
may be more prevalent throughout the life history of green turtles, especially ETP turtles, than the standard understanding of their life history suggests. The size range of the turtles in our study also indicates the likelihood of an extended pelagic stage, with five of the 10 greens sampled measuring larger than the average recruit size of $40-45 \mathrm{~cm}$, four with ETP morphology and three genetically confirmed to be ETP animals. The occurrence of green turtles in Alaska (Hodge and Wing 2000) also suggests extended pelagic foraging. Green turtles recorded off Alaska are mainly from stranding of turtles on remote islands open to the Alaska Current. Most of these stranded turtles had the morphology of ETP green turtles and were larger than $60 \mathrm{~cm}$ CCL (Hodge and Wing 2000; PIFSC, unpubl. data). Although there may be sea grass or algae available along the Pacific Northwest coast for neritic foraging, prey items identified from the turtles that were necropsied indicated a pelagic diet (Carinaria spp. and Pyrosoma spp., PIFSC, unpubl. data).

Because of the small sample size in our study, additional research is needed to fully document the oceanic habitat and oceanic foraging ecology of the green turtle. Because sea turtles are rarely observed or scientifically sampled in the open ocean, obtaining information on the oceanic stage of the green turtle is mainly confined to a relatively few samples from fisheries bycatch. In fisheries as well as surveys in the Pacific, only 6\%-9\% of the turtles encountered over multiple years have been identified as green turtles (Wetherall et al. 1993, Alfaro-Shigueto et al. 2002, Donoso and Dutton 2010; R. Pitman unpubl. data). Total numbers of all turtle species caught in these fisheries could vary between a couple of hundred to a couple of thousand depending on year, area fished, fishing gear used, and many other variables. However, obtaining turtles from fisheries bycatch for scientific research is often hindered by lack of collection or Convention on International Trade in Endangered Species of Wild Fauna and Flora (CITES) permits and also lack of adequate storage facilities aboard fishing vessels to properly preserve scientific samples. Research is also needed to more fully docu- ment the movements of green turtles with eastern Pacific morphology to the west of Mexico and south of the Hawaiian Islands to determine which nesting populations these turtles may originate from. These turtles are of particular interest because they exhibit a life history of an extended pelagic stage that is different from the usual understanding of green turtle life history, so more information about these turtles would be beneficial.

\section{ACKNOWLEDGMENTS}

We thank the NMFS seagoing observers for their dedicated work in collecting the carcasses of the turtles accidentally taken as bycatch. We thank J. Seminoff, S. Hargove, M. Rice, B. Mundy, and two other reviewers for their suggestions and comments. We also thank E. LaCasella, V. Pease, A. Jue, and R. LeRoux for their tireless efforts with genetic laboratory work for this study.

\section{Literature Cited}

Alfaro-Shigueto, J., M. Van Bressem, D. Montes, K. Onton, D. Vega, and K. Van Waerebeek. 2002. Turtle mortality in fisheries off the coast of Peru. Pages 86-88 in A. Mosier, A. Foley, and B. Brost, comps. Proceedings of the 20th Annual Symposium on Sea Turtle Biology and Conservation. U.S. Dep. Commer., NOAA Tech. Memo. NMFS-SEFSC-477.

Allen, W. 1992. Loggerhead dies after ingesting marine debris. Mar. Turtle Newsl. $58: 10$.

Amorocho, D. F., and R. D. Reina. 2007. Feeding ecology of the East Pacific green sea turtle Chelonia mydas agassizii at Gorgona National Park, Colombia. Endang. Species Res. 3:43-51.

Arenas, P., and M. Hall. 1991. The association of sea turtles and other pelagic fauna with floating objects in the eastern tropical Pacific Ocean. Pages 7-10 in M. Salmon and J. Wyneken, comps. Proceedings of the 11th Annual Workshop on Sea Turtle Biology and Conservation. U.S. Dep. Commer., NOAA Tech. Memo. NMFSSEFSC-302. 
Arthur, K. E., and G. H. Balazs. 2008. A comparison of immature green turtle (Chelonia mydas) diets among seven sites in the Main Hawaiian Islands. Pac. Sci. 62:205217.

Balazs, G. H. 1980. Synopsis of biological data on the green turtle in the Hawaiian Islands. U.S. Dep. Commer., NOAA Tech. Memo. NOAA-TM-NMFS-SWFC-7.

- 1985. Impact of ocean debris on marine turtles: Entanglement and ingestion. Pages 387-429 in R. S. Shomura and H. O. Yoshida, eds. Proceedings of the Workshop on the Fate and Impact of Marine Debris, 26-29 November 1984, Honolulu, Hawai'i. U.S. Dep. Commer., NOAA Tech. Memo. NOAA-TM-NMFSSWFC-54.

- 1986. Ontogenetic changes in the plastron pigmentation of hatchling Hawaiian green turtles. J. Herpetol. 20:280-282.

Balazs, G. H., R. G. Forsyth, and A. K. H. Kam. 1987. Preliminary assessment of habitat utilization by Hawaii green turtles in their resident foraging pastures. U.S. Dep. Commer., NOAA Tech. Memo. NOAA-TM-NMFS-SWFC-71.

Barry, C. 2009. Plastics break down in the ocean after all-and fast. Natl. Geogr. News, 20 August (http://news. nationalgeographic.com/news/2009/08/ 090820-plastic-decomposes-oceans-seas .html) (accessed 5 May 2010).

Bjorndal, K. A. 1985. Nutritional ecology of sea turtles. Copeia 1985:736-751.

1997. Foraging ecology and nutrition of sea turtles. Pages 199-231 in P. L. Lutz and J. A. Musick, eds. The biology of sea turtles. CRC Press, London.

Boyle, M. C., and C. J. Limpus. 2008. The stomach contents of post-hatchling green and loggerhead sea turtles in the Southwest Pacific: An insight into habitat association. Mar. Biol. (Berl.) 155:233-241.

Burke, V. J., S. J. Morreale, P. Logan, and E. A. Standora. 1991. Diet of green turtles (Chelonia mydas) in the waters of Long Island, N.Y. Pages 140-142 in M. Salmon and J. Wyneken, comps. Proceedings of the 11th Annual Workshop on Sea Turtle Biology and Conservation. U.S. Dep.
Commer., NOAA Tech. Memo. NMFSSEFSC-302.

Bustard, H. R. 1970. The adaptive significance of coloration in hatchling green sea turtles. Herpetologica 26:224-227.

Caldwell, D. K. 1963. The sea turtle fishery of Baja California, Mexico. Calif. Fish Game 49:140-151.

Carr, A. F. 1952. Handbook of turtles. Cornell University Press, Ithaca, New York. - 1967. So excellent a fishe: A natural history of sea turtles. Natural History Press, New York.

Carr, A., and A. B. Meylan. 1980. Evidence of passive migration of green turtle hatchlings in Sargassum. Copeia 2:366-368.

Cheng, I.-J., P. H. Dutton, C.-L. Chen, H.-C. Chen, W.-H. Chen, and J.-W. Shea. 2008. Comparison of the genetics and nesting ecology of two green turtle rookeries. J. Zool. (Lond.) 276:375-384.

Collette, B. B., and C. R. Aadland. 1996. Revision of the frigate tunas (Scombridae, Auxis) with descriptions of two new subspecies from the eastern Pacific. Fish. Bull. 94:423-441.

Davenport, J., and G. H. Balazs. 1991. 'Fiery bodies': Are pyrosomas an important component of the diet of leatherback turtles. Br. Herpetol. Soc. Bull. 37:33-38.

Day, R. H., D. G. Shaw, and S. E. Ingell. 1990. The quantitative distribution and characteristics of neuston plastic in the North Pacific Ocean, 1985-1988. Pages 247-266 in R. S. Shomura and M. L. Godfrey, eds. Proceedings of the 2nd International Conference on Marine Debris, 2-7 April 1989, Honolulu, Hawai'i. U.S. Dep. Commer. NOAA Tech. Memo. NOAATM-NMFS-SWFSC-154.

Dethmers, K. E. M., D. Broderick, C. Moritz, N. N. Fitzsimmons, C. J. Limpus, S. Lavery, S. Whiting, M. Guinea, R. I. T. Prince, and R. Kennett. 2006. The genetic structure of Australasian green turtles (Chelonia mydas): Exploring the geographical scale of genetic exchange. Mol. Ecol. 15:39313946.

Donoso, M., and P. H. Dutton. 2010. Sea turtle bycatch in the Chilean pelagic longline fishery in the southeastern Pacific: 
Opportunities for conservation. Biol. Conserv. 143:2672-2684.

Dutton, P. H., and G. Balazs. 1995. Simple biopsy technique for sampling skin for DNA analysis of sea turtles. Mar. Turtle Newsl. 69:9-10.

Dutton, P. H., G. H. Balazs, R. A. LeRoux, S. K. K. Murakawa, P, Zárate, and L. S. Martínez. 2008. Composition of Hawaiian green turtle foraging aggregations: mtDNA evidence for a distinct regional population. Endang. Species Res. 5:37-44.

Dutton, P. H., E. Bixby, R. A. LeRoux, and G. Balazs. 2000. Genetic stock origin of sea turtles caught in the Hawaii-based longline fishery. Pages 120-121 in H. J. Kalb and T. Wibbels, comps. Proceedings of the 19th Annual Symposium on Sea Turtle Biology and Conservation. U.S. Dep. Commer., NOAA Tech. Memo. NMFS-SEFSC-443.

Dutton, P. H., S. K. Davis, T. Guerra, and D. Owens. 1996. Molecular phylogeny for marine turtles based on sequences of the ND4-leucine tRNA and control regions of mtDNA. Mol. Phylogenet. Evol. 5:511521.

Ebeling, A. W., and W. H. Weed III. 1963. Melamphaidae III: Systematics and distribution of the species in the bathypelagic fish genus Scopelogadus Vaillant. Dana-Rep. Carlsberg Found. 60.

Ellis, D. M., and G. H. Balazs. 1998. Use of the generic mapping tool program to plot ARGOS tracking data for sea turtles. Page 177-179 in S. P. Epperly and J. Braun, comps. Proceedings of the 17th Annual Sea Turtle Symposium. U.S. Dep. Commer., NOAA Tech. Memo. NMFSSEFSC-415.

Ferreira, B., M. Garcia, B. P. Jupp, and A. AlKiyumi. 2006. Diet of the green turtle (Chelonia mydas) at Ra's Al Hadd, Sultanate of Oman. Chelonian Conserv. Biol. 5:141146.

Figueroa, A., and J. Alvarado. 1991. Morphometric comparison of the Chelonia populations of Michoacan, Mexico, and Tortuguero, Costa Rica. U.S. Dep. Commer., NOAA Tech. Memo. NMFS-SEFC-278: 179-182.
Gill, V. 2010. Plastic rubbish blights Atlantic Ocean. BBC News, 24 February (http:// news.bbc.co.uk/2/hi/science/nature/ 8534052.stm) (Accessed 10 May 2010).

Groombridge, B., and R. Luxmoore. 1989. The green turtle and hawksbill (Reptilia: Cheloniidae): World status, exploitation, and trade. CITES Secretariat, Lausanne, Switzerland.

Hatase, H., K. Sato, M. Yamaguchi, K. Takahashi, and K. Tsukamoto. 2006. Individual variation in feeding habitat use by adult female green sea turtles (Chelonia mydas): Are they obligate neritic herbivores? Oecologia (Berl.) 149:52-64.

Hays-Brown, C., and W. M. Brown. 1982. Status of sea turtles in the southeastern $\mathrm{Pa}$ cific: Emphasis on Peru. Pages 235-240 in K. A. Bjorndal, ed. Biology and conservation of sea turtles. Smithsonian Institution Press, Washington, D.C.

Hellawell, J. M., and R. Abel. 1971. A rapid volumetric method for the analysis of the food of fishes. J. Fish Biol. 3:29-37, doi:10.1111/j.1095-8649.1971.tb05903.x.

Highsmith, R. C. 1985. Floating and algal rafting as potential dispersal mechanisms in brooding invertebrates. Mar. Ecol. Prog. Ser. 25:169-179.

Hilton-Taylor, C., comp. 2000. 2000 IUCN Red list of threatened species. IUCN, Gland, Switzerland and Cambridge, U.K.

Hodge, R. P., and B. L. Wing. 2000. Occurrences of marine turtles in Alaska waters: 1960-1998. Herpetol. Rev. 31:148-151.

Hubbs, C. L., and R. L. Wisner. 1980. Revision of Sauries (Pisces, Scoberesocidae) with descriptions of two new genera and one new species. Fish. Bull. 77:521-566.

Jokiel, P. F. 1989. Rafting of reef corals and other organisms at Kwajalein Atoll. Mar. Biol. (Berl.) 101:483-493.

Lahanas, P. N., M. M. Miyamoto, K. A. Bjorndal, and A. B. Bolten. 1994. Molecular evolution and population genetics of greater Caribbean green turtles (Chelonia mydas) as inferred from mitochondrial DNA control region sequences. Genetica (The Hague) 94:57-67.

Lessios, H. A., and D. R. Robertson. 2006. Crossing the impassable: Genetic connec- 
tions in 20 reef fishes across the eastern Pacific barrier. Proc. R. Soc. B 273:22012208.

Limpus, C. J. 1978. The reef and uncertain land of plenty. Pages 187-222 in H. Lavery, ed. Exploration north: A natural history of Queensland. Richmond Hill Press, Melbourne.

Limpus, C. J., P. J. Couper, and M. A. Read. 1994. The green turtle, Chelonia mydas, in Queensland: Population structure in a warm temperate feeding area. Mem. Queensl. Mus. 35:139.

McCauley, S. J., and K. A. Bjorndal. 1999. Conservation implications of dietary dilution from debris ingestion: Sublethal effects in post-hatchling loggerhead sea turtles. Conserv. Biol. 13:925-929.

McLendon, R. 2010. What is the great $\mathrm{Pa}-$ cific Ocean garbage patch? Mother $\mathrm{Na}$ ture Network, 24 February (http://www .mnn.com/earth-matters/translatinguncle-sam/stories/what-is-the-greatpacific-ocean-garbage-patch) (Accessed 3 May 2010).

Moore, C. J., S. L. Moore, M. K. Leecaster, and S. B. Weisberg. 2001. A comparison of plastic and plankton in the North Pacific central gyre. Mar. Pollut. Bull. 42:12971300 .

Mortimer, J. A. 1982. Feeding ecology of sea turtles. Pages 103-110 in K. A. Bjorndal, ed. Biology and conservation of sea turtles. Smithsonian Institution Press, Washington, D.C.

Musick, J. A., and C. J. Limpus. 1997. Habitat utilization of migration in juvenile sea turtles. Pages 137-164 in P. L. Lutz and J. A. Musick, eds. The biology of sea turtles. CRC Press, Boca Raton, Florida.

Myers, R. F. 1999. Micronesian reef fishes: A field guide for divers and aquarists. Coral Graphics, Barrigada, Guam.

National Marine Fisheries Service and U.S. Fish and Wildlife Service. 1998a. Recovery plan for U.S. Pacific populations of the green turtle (Chelonia mydas). National Marine Fisheries Service, Silver Spring, Maryland.

- 1998b. Recovery plan for U.S. Pacific populations of the East Pacific green turtle
(Chelonia mydas). National Marine Fisheries Service, Silver Spring, Maryland.

Nichols, W. J., L. Brooks, M. Lopez, and J. A. Seminoff. 2001. Record of pelagic East $\mathrm{Pa}$ cific green turtles associated with Macrocystis mats near Baja California Sur, Mexico. Mar. Turtle Newsl. 93:10-11.

Parker, D. M., W. J. Cooke, and G. H. Balazs. 2005. Diet of oceanic loggerhead sea turtles (Caretta caretta) in the central North Pacific. Fish. Bull. 103:142-152.

Pichel, W., J. Churnside, T. Veenstra, D. Foley, K. Friedman, R. Brainard, J. Nicoll, Q. Zheng, and P. Clemente-Colon. 2007. Marine debris collects within the North Pacific subtropical convergence zone. Mar. Pollut. Bull. 54:1207-1211.

Pitman, R. 1990. Pelagic distribution and biology of sea turtles in the eastern tropical Pacific. Pages 143-148 in T. H. Richardson, J. I. Richardson, and M. Donnelly, comps. Proceedings of the 10th Annual Workshop on Sea Turtle Biology and Conservation. U.S. Dep. Commer., NOAA Tech. Memo. NMFS-SEFC-278.

Pritchard, P. C. H. 1977. Marine turtles of Micronesia. Chelonia 3 (4): 1-83.

Pritchard, P. C. H., and P. Trebbau. 1984. The turtles of Venezuela. Society for the Study of Amphibians and Reptiles, Athens, Ohio.

Reich, K. J., K. A. Bjorndal, and A. B. Bolten. 2007. The 'lost years' of green turtles: Using stable isotopes to study cryptic lifestages. Biol. Lett. 3:712-714.

Rice, M. R., and G. H. Balazs. 2008. Diving behavior of the Hawaiian green turtle (Chelonia mydas) during oceanic migrations. J. Exp. Mar. Biol. Ecol. 365:121127.

Salmon, M., T. T. Jones, and K. W. Horch. 2004. Ontogeny of diving and feeding behavior of juvenile seaturtles: Leatherback seaturtles (Dermochelys coriacea L.) and green seaturtles (Chelonia mydas L.) in the Florida Current. J. Herpetol. 38:36-43.

Seminoff, J. A. 2004. Chelonia mydas. In IUCN, 2010, 2010 IUCN Red list of threatened species (http://www.iucnredlist .org/apps/redlist/details/4615/0) (Accessed 12 April 2011). 
Seminoff, J. A., T. T. Jones, A. Resendiz, W. J. Nichols, and M. Y. Chaloupka. 2003. Monitoring green turtles (Chelonia mydas) at a coastal foraging area in Baja California, Mexico: Multiple indices to describe population status. J. Mar. Biol. Assoc. U.K. 83:1355-1362.

Seminoff, J. A., A. Resendiz, and W. J. Nichols. 2002. Diet of East Pacific green turtles (Chelonia mydas) in the central Gulf of California, Mexico. J. Herpetol. 36:447-453.

Seminoff, J. A., P. Zárate, M. Coyne, D. G. Foley, D. Parker, B. N. Lyon, and P. H. Dutton. 2008. Post-nesting migrations of Galápagos green turtles, Chelonia mydas, in relation to oceanographic conditions: Integrating satellite telemetry with remotely sensed ocean data. Endang. Species Res. 4:57-72.

Senko, J., M. C. López-Castro, V. Koch, and W. J. Nichols. 2010. Immature East Pacific green turtles (Chelonia mydas) use multiple foraging areas off the Pacific coast of Baja California Sur, Mexico: First evidence from mark-recapture data. Pac. Sci. 64:125-130.

Shaver, D. J., and P. T. Plotkin. 1998. Marine debris ingestion by sea turtles in South Texas: Pre- and post-MARPOL ANNEX V. Page 124 in R. Byles and Y. Fernandez, comps. Proceedings of the 16th Annual Symposium on Sea Turtle Biology and Conservation. U.S. Dep. Commer. NOAA Tech. Memo. NMFS-SEFSC-412.

Smith, M. M., and M. Salmon. 2009. A comparison between the habitat choices made by hatchlings and juvenile green turtles (Chelonia mydas) and loggerheads (Caretta caretta). Mar. Turtle Newsl. 126:9-13.

Thil, M., and L. Gutow. 2005. The ecology of rafting in the marine environment. II. The rafting organisms and community. Oceanogr. Mar. Biol. Annu. Rev. 43:279418.

Tomás, J. R., R. Guitart, R. Mateo, and J. A. Raga. 2002. Marine debris ingestion in loggerhead sea turtles, Caretta caretta, from the western Mediterranean. Mar. Pollut. Bull. 44:211-216.

Vroom, P. S., K. N. Page, K. A. Peyton, and J. K. Kukea-Shultz. 2006. Marine algae of French Frigate Shoals, Northwestern Hawaiian Islands: Species list and biogeographic comparisons. Pac. Sci. 60:81-95.

Wessel, P., and W. H. F. Smith. 1991. Free software helps map and display data. EOS Trans. AGU 72:441, 445-446.

Wetherall, J.A., G. H. Balazs, R. A. Tokunaga, and M. Y. Y. Yong. 1993. By-catch of marine turtles in North Pacific high seas driftnet fisheries and impacts on the stock. Pages 519-538 in J. Ito et al., eds. INPFC Symposium on biology, distribution and stock assessment of species caught in the high seas driftnet fisheries in the North Pacific Ocean. Bull. Int. North Pac. Fish. Comm. 53 (III). Vancouver, Canada.

Witherington, B. E. 2002. Ecology of neonate loggerhead turtles inhabiting lines of downwelling near a Gulf Stream front. Mar. Biol. (Berl.) 140:843-853.

Work, T. M., and G. H. Balazs. 2002. Necropsy findings in sea turtles taken as bycatch in the North Pacific longline fishery. Fish. Bull. 100:876-880.

- 2010. Pathology and distribution of sea turtles landed as by-catch in the Hawaii-based North Pacific pelagic longline fishery. J. Wildl. Dis. 46:422-432.

Wrobel, D., and C. Mills. 1998. Pacific coast pelagic invertebrates: A guide to the common gelatinous animals. Sea Challengers and Monterey Bay Aquarium Publication, Global Interprint, Petaluma, California.

Wyneken, J. 2001. The anatomy of sea turtles. U.S. Dep. Commer., NOAA Tech. Memo. NMFS-SEFSC-470.

Zug, G. R., G. H. Balazs, J. A. Wetherall, D. M. Parker, and S. K. K. Murakawa. 2002. Age and growth of Hawaiian green sea turtles (Chelonia mydas): An analysis based on skeletochronology. Fish. Bull. 100:117-127. 
